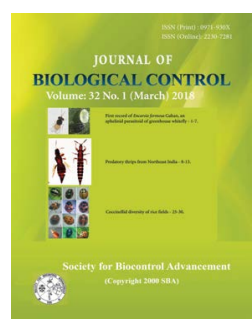

\title{
On the collections of predatory thrips (Insecta: Thysanoptera) from NE India
}

\author{
R. VARATHARAJAN ${ }^{1}$, K. NISHIKANTA SINGH ${ }^{1}$ and R. R. RACHANA ${ }^{2 *}$ \\ ${ }^{1}$ Centre of Advanced Study in Life Sciences, Manipur University, Imphal - 795003, Manipur, India \\ ${ }^{2}$ National Bureau of Agricultural Insect Resources (ICAR-NBAIR), Bengaluru - 560024, Karnataka, India \\ *Corresponding author E-mail: vavarachana@gmail.com
}

\begin{abstract}
A dozen species of predatory thrips collected from the national parks and wildlife sanctuaries of biodiversity rich northeastern India, belonging to 9 genera in 3 families viz., Aeolothripidae, Thripidae and Phlaeothripidae are reported here with the details of their habitat, prey species that they encounter and geographic distribution of predator along with the key to identify them. The data on predatory thrips of NE India showed that the aeolothripids are represented by 6 species in 5 genera, thripids by a genus and a species and the phlaeothripids by 5 species in 3 genera.
\end{abstract}

KEY WORDS: Bio-Control, Hotspots of NE India, Species Diversity, Thysanoptera

(Article chronicle: Received: 02-06-2017; Revised: 05-02-2018; Accepted: 18-03-2018)

\section{INTRODUCTION}

Thrips (Thysanoptera) constitute an economically important group of minute insects with the body length ranging from $0.5-15 \mathrm{~mm}$. They comprise 6147 extant species in 781 genera (Thrips Wiki accessed on 27/4/2017), of which, nearly $50 \%$ of them are fungal feeders, another $40 \%$ live on tissues of plants. Some species are predatory and therefore serve as bio-control agents of arthropod pests (Cox et al. 2006; Morse and Hoddle, 2006). A number of thrips species are well known vectors of plant diseases besides pests of important crops (Mound et al. 2010). The family Aeolothripidae under the suborder Terebrantia includes merely about $5 \%$ of the total described species, i.e., with 194 extant species in 23 genera worldwide (ThripsWiki referred on 27/4/2017) and they exhibit a wide range of feeding diversity, from obligate phytophagous to facultative predators of small arthropods that live in flowers (Mound, 1997; Mound and Marullo, 1998). Among phlaeothripids of the suborder Tubulifera, majority are fungal feeders and the rest constitute plant sap sucking forms, and a proportion of which predate upon mites, thrips and coccids (Mound, 1997). A number of researchers have recorded occurrence of diverse species of predatory thrips from different parts of the world (Lewis, 1973; Ananthakrishnan, 1976; Okajima et al., 1992; Hirose et al., 1993; Kirk, 1997; Arakaki and Okajima, 1998; Mound and Reynaud, 2005; Saengyot, 2016). But information pertaining to predatory thrips of northeastern India is meager and therefore, the present paper presents diversity, diagnostic features, distribution, and prey range of predatory thrips that were collected from the national parks and wildlife sanctuaries of biodiversity rich NE India along with the key to identify them.

\section{MATERIAL AND METHODS}

Thrips survey was undertaken during the last five years under the DST sponsored research project with the aim to record thrips fauna from the national parks, wildlife sanctuaries, and other forest areas of northeastern India. Collection was done during spring and autumn seasons of the year coinciding with the phenology of flowers (blooming period) in general and the samples were taken at random from varied plants growing in diverse habitats and the collected thrips were preserved in the specific collection fluid with the composition of $10 \%$ ethanol, glacial acetic acid and glycerol in 9:1:1 ratio with a few drops of Triton-X (Bhatti, 1997). Standard protocol was followed to prepare permanent slides for the purpose of identification and permanent preservation (Ananthakrishnan and Sen, 1980) and the images of the identified specimens were photographed with the help of Olympus Trinocular Research Microscope- 
CX-31. The permanent slides of the specimens were deposited in the Department of Life Sciences, Manipur University and some at the ICAR- National Bureau of Agricultural Insect Resources (NBAIR), Bengaluru.

\section{RESULTS}

The survey carried out at different parts of northeast- ern India revealed the occurrence of 12 species of predatory thrips belonging to 9 genera in three families of the order Thysanoptera. The family Aeolothripidae was represented by 6 species in 5 genera, Thripidae by a genus and a species and Phlaeothripidae by 5 species in 3 genera. The systematic account of all the 12 species of predatory thrips along with their distribution, prey species and plant host are presented
A
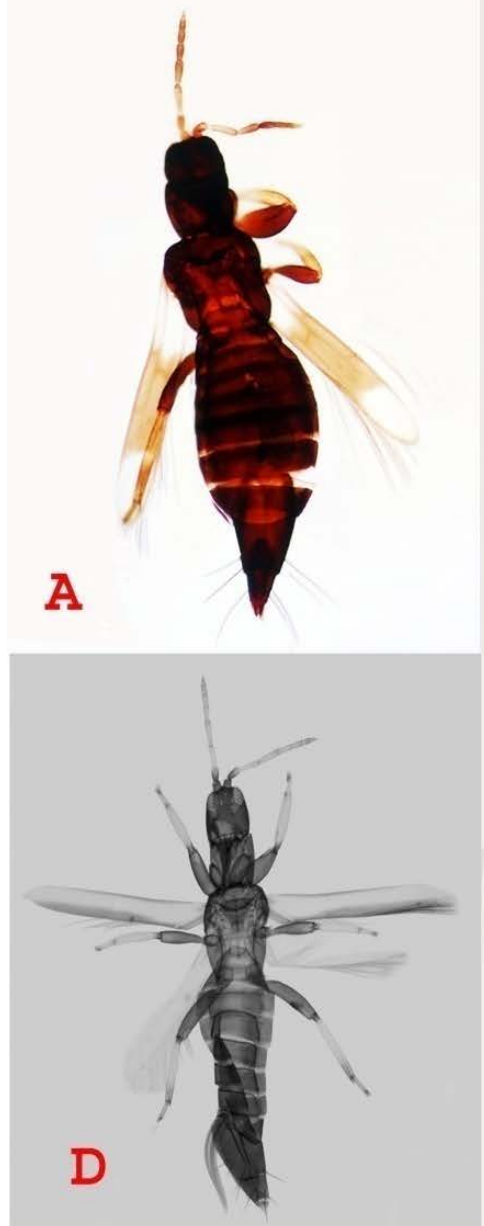

G

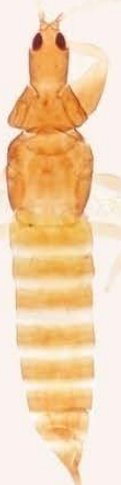

E

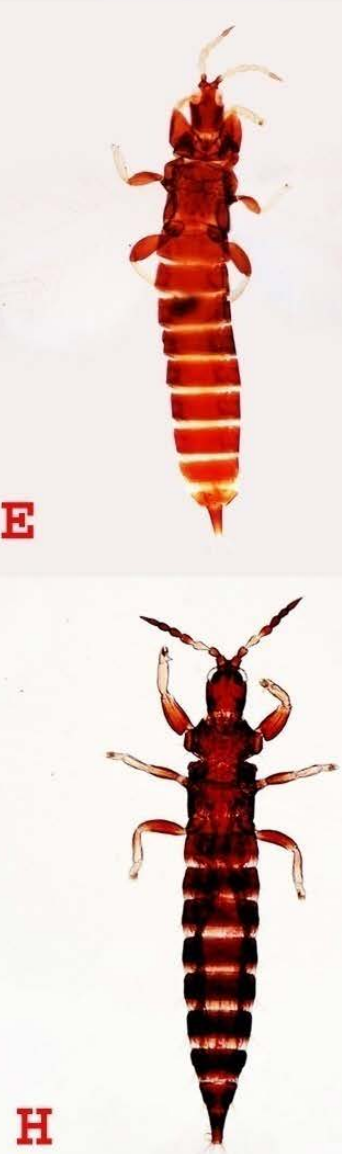

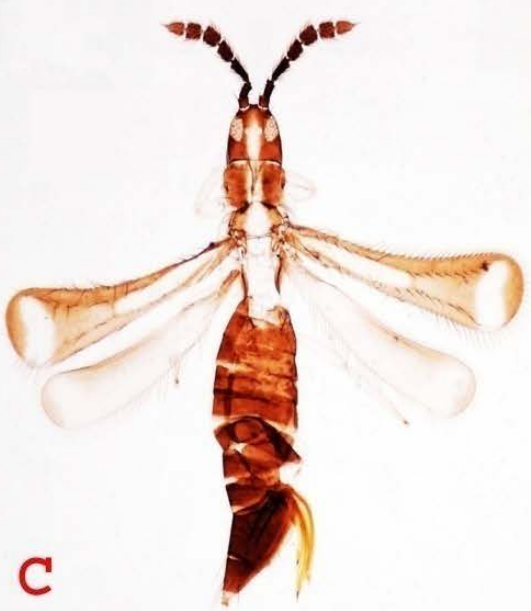

F

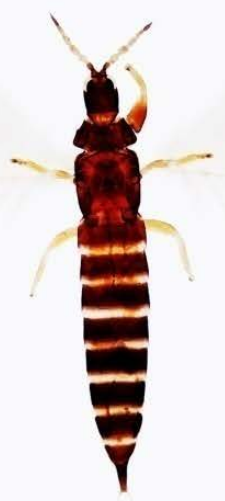

I

Fig. 1. A. Aeolothrips collaris, B. Franklinothrips vespiformis, C. Mymarothrips garuda, D. Aduncothrips asiaticus, E. Androthrips flabitibia, F. Androthrips flavipes, G. Androthrips ramachandrai, H. Karnyothrips flavipes and I. Aleurodothrips fasciapennis. 
below:

\section{Order Thysanoptera \\ Suborder Terebrantia \\ Family Aeolothripidae Uzel}

\section{Aduncothrips Ananthakrishnan 1964}

1. Aduncothrips asiaticus (Ramak. and Marg., 1931). (Figure D)

Host plant: Anacardium occidentale L. (Anacardiaceae).

Prey: Selenothrips rubrocintus (Giard).

Distribution: India (Karnataka, Tamil Nadu, Manipur: Moreh - Tamu areas of Indo-Myanmar border). This species is recorded so far only from India.

\section{Aeolothrips Haliday, 1836}

2. Aeolothrips collaris Priesner, 1919. (Figure A)

Host plants: Found in different flowering plants and a facultative predator collected from wild flowers grown in adjoining areas of tea field, Mokokchung, Nagaland and also from Chailenyta, Tripura.

Prey: Scirtothrips dorsalis Hood and Thrips hawaiiensis (Morgan).

Distribution: Afghanistan, China, India (Nagaland and Tripura), Europe, Mongolia, North America, Syria.

\section{Indothrips Bhatti, 1967}

3. Indothrips bhusani Bhatti, 1967.

Host plant: Ficus leaf

Prey: Liothrips spectabilis Ananthakrishnan

Distribution: India (Manipur, Madhya Pradesh, Rajasthan, Delhi, Uttar Pradesh) and Iran.

\section{Mymarothrips Bagnall, 1928}

4. Mymarothrips garuda Ramakrishna \& Margabandhu, 1931. (Figure C)

Host plant: Leaves of Curcuma longa L. (Zingiberaceae).

Prey: Pancheatothrips indicus Bagnall.

Distribution: China and India (Itanagar wildlife sanctuary of Arunachal Pradesh, Tamil Nadu).

\section{Franklinothrips Back, 1912}

5. Franklinothrips megalops (Trybom, 1912).

Host plants: leaves of Morus alba L. (Moraceae).

Prey: Thrips hawaiiensis (Morgan)

Distribution: southern and eastern Africa and India (Meghalaya, Tamil Nadu and Tripura).

6. Franklinothrips vespiformis (Crawford DL, 1909). (Figure B)

Host plants: Tea leaves from the tea gardens of Connoor (Tamil Nadu) and Cachar district, Assam; Avocado trees.
Prey: Scirtothrips bispinosos (Bagnall) \{in Connoor $\}$; S.dorsalis Hood; Thrips hawaiiensis (Morgan)

\section{Family Thripidae}

Scolothrips Hinds, 1902

7. Scolothrips asura Ramakrishna and Margabandhu, 1931. Habitat: Leaves and flowers of field crops.

Prey: Thrips sp.

Distribution: Australia, Japan, Taiwan and India (Tripura and Coimbatore in Tamil Nadu). Occurrence of this specimen in NE India is based on the report provided by Sen et al. (1988) in the Records of ZSI, Kolkata.

\section{Suborder Tubulifera Haliday \\ Family Phlaeothripidae \\ Subfamily Phlaeothripinae Uzel}

\section{Aleurodothrips Franklin, 1909}

8. Aleurodothrips fasciapennis (Franklin, 1908). (Figure I) Habitat: Bambusa sp. (Poaceae).

Prey: Xylaplothrips inquilinus (Priesner).

Distribution: West Indies, Australia and India (Karnataka, Manipur - Keibul Lamjao National Park)

\section{Androthrips Karny, 1911}

9. Androthrips flavipes Schmutz, 1913. (Figure F)

Habitat: Schefflera sp.

Prey: Liothrips himalayanus Ananthakrishnan and Jagadish Distribution: India (Assam, Kerala, Manipur - Keibul Lamjao National Park, Meghalaya, Tripura, Tamil Nadu) \& Sri Lanka.

10. Androthrips flavitibia Moulton, 1933. (Figure E) Habitat: Galls of Mallotus sp. (Euphorbiaceae); collected from Cachar, Assam.

Prey: Liothrips bosei Moulton

Distribution: India (Assam, Manipur - Keibul Lamjao National Park, Uttar Pradesh).

Remark: Recorded only from India till now.

11. Androthrips ramachandrai Karny, 1926. (Figure G)

Habitat: Pouch galls of unidentified plant; collected from Kaziranga National Park and Cachar hills, Assam.

Prey: Gynaikothrips bengalensis Ananthakrishnan and Gigantothrips elegans Zimmerman

Distribution: India (Assam, Tamil Nadu), Japan and America.

\section{Karnyothrips Watson, 1923}

12. Karnyothrips flavipes (Jones, 1912). (Figure H) Habitat: Setaria italica (Linn.) Beauv. (Poaceae). Prey: Anaphothrips sudanensis Trybom 
Distribution: India (Manipur - Keibul Lamjao National Park, Kerala and Tamil Nadu), Australia, Egypt and USA.

\section{Key to Identify Predatory Thrips of NE India \\ Key to the Families of Predatory Terebrantians}

1. Ovipositor curved upwards. Forewings broad $\&$ rounded at apex; front margin without the fringe of long hairs. Antennae 9 segmented......... Family Aeolothripidae Ovipositor curved downwards. Forwings generally pointed at apex; front margin with the fringe of hairs. Anetnnae 7-8 segmented, rarely 9 segmented......... Family Thripidae

\section{Key to Genera of Predatory Thrips in Aeolothripidae}

1. Forewings almost parallel sided, with or without cross bars. 2

- Forewings not parallel sided, but widened at apex......... 3

2. Head produced in front of eyes. Antennae with rigid setae; segments 3 and 4 with broad lens shaped sensoria ventrally at apex. Maxillary palp 2 segmented, labial palp 3 segmented. Wings moderately broad; straight fringes along the costal margin. .................... Indothrips Bhatti

- Head not produced. Antennae without rigid setae; segments 5-8 with elongated sensoria. Maxillary palp 5 segmented, labial palp 4 segmented......... Aduncothrips Ananthakrishnan

3. Only one pair of accessory setae present laterally on the sternite VI....................................................................

- No accessory setae on sternite III-VI. Sternite VII of female with 2 pairs of accessory setae close to the midline and no accessory setae laterally on VII sternite. ..... Aeolothrips Haliday

4. Forewings widened at apex, racket like. Maxillary palp 8- segmented; labial palp 4 segmented. Antennae stout with rigid prominent bristles ..... Mymarothrips Bagnall

- Forewings not much widened at apex. Maxillary palp 3 segmented. Antennae long \& thin; segment 3 nearly 10 times as long as wide; sensoria on segment 3 and 4 extending along the whole length of the segments Franklinothrips Back

\section{Key to Predatory Thrips Genus of the Family Thripidae}

1. Body brightly coloured, with the head, meso- and metathorax \& abdominal segments VI-VIII brown; pronotum, legs \& abdominal segments I-V and IX-X white in colour; bright red internal pigments in brown body parts. 6 pairs of long \& barbed setae on pronotum. 1 pair of prominent setae on head between the ocelli. Forewings banded with a series of setae. Scolothrips Hinds

Key to the Subfamily and Genera under Phlaeothripidae

1. Maxillary stylets slender, not broad and narrower than labial palps. Phlaeothripinae Priesner

2. Forewings banded, narrow, widened at base. Males with well developed spur on the inner side of the forefemora. Pronotal setae not expanded at apex..................... Aleurodothrips Franklin

- Forewings not banded. Males without spur on the inner side of the fore femora. Pronotal setae expanded at the base.

3. Fore femora and fore tibia unarmed; fore tarsi armed or unarmed. Fore femora in females without either tooth or hump. Fore tibia without scale at apex..Karnyothrips Watson - Fore femora, fore tibia and fore tarsi variously armed; fore femora in females with a blunt tooth or hump at base, often crenulate. Foretibia with scale at apex Androthrips Karny

- All legs yellow.. 3 (A)

- All legs not uniformly yellow.....

3(A). All legs yellow; body pale to dark brown. Postoculars $(55-65 \mu)$ and prothoracic postangulars $(93 \mu)$ and epimerals

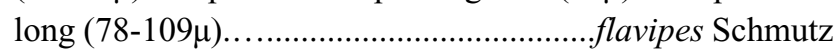
3(B). Forefemora brown, shading to yellow in outer third; mid- and hind femora brown; all tibiae yellow. Postoculars $(83 \mu)$ and prothoracic $(93 \mu)$ and epimerals $(104 \mu)$ long. ...flabitibia Moulton

- Apex of forefemora, entire foretibiae, extreme base of hindtibiae and all tarsi yellow; rest dark brown. Body setae well developed and long. Fore femora with a conspicuous row of tubercles at inner margin. ramachandrai Karny

\section{DISCUSSION}

Utility of predatory thrips as effective bio-control agent has been well documented and different researchers have successfully augmented and practiced the application of predatory thrips in the field of biological control. To mention a few, Franklinothrips orizabensis Johansen had been extensively studied for its biology and predatory efficacy on avocado thrips, Scirtothrips perseae Nakahara (Thysanoptera: Thripidae) and the predator $F$. orizabensis has been mass reared and marketed in Europe as an efficient bio-control agent against thrips in greenhouses (Hoddle et al., 2004; Mound and Reynaud, 2005). Aeolothrips intermedius Bagnall (Aeolothripidae) was used along with the anthocorid, Orius niger (Wolff) for the control of field populations of Thrips tabaci Lindeman (Fathi et al. 2008), Frankliniella occidentalis (Pergande) and $T$. tabaci (Tommasini and Nicoli, 2002; Blaeser et al., 2004). The discovery of bacterial endosymbiont, Wolbachia from the body of Franklinothrips vespiformis gave yet another dimension that they not only serve as endosymbionts but also capable of inducing $F$. vespiformis to produce only female progeny by the process of thelytokous mode of parthenogenesis. Females of this species are not only bigger 
Table 1. List of predatory thrips and the prey species along with the plant-hosts

\begin{tabular}{|c|c|c|c|}
\hline $\begin{array}{l}\text { Sl. } \\
\text { No. }\end{array}$ & Name of the Predatory thrips & Prey species & Plant Host \\
\hline 1 & $\begin{array}{l}\text { Aduncothrips asiaticus* } \\
\text { (Terebrantia: Aelothripidae) }\end{array}$ & Selenothrips rubrocinctus (Giard) & Anacardium occidentale L. \\
\hline 2 & $\begin{array}{l}\text { Aeolothrips collaris } \\
\text { (Terebrantia: Aelothripidae) }\end{array}$ & $\begin{array}{l}\text { Scirtothrips bispinosus Bagnall, S. dorsalis } \\
\text { Hood and Thrips hawaiiensis (Morgan) }\end{array}$ & Tea plant- Camellia chinensis \\
\hline 3 & $\begin{array}{l}\text { Aleurodothrips fasciapennis } \\
\text { (Tubulifera: Phlaeothripidae) }\end{array}$ & $\begin{array}{l}\text { Xylaplothrips inquilinus } \\
\text { (Priesner) }\end{array}$ & Bambusa sp. \\
\hline 4 & $\begin{array}{l}\text { Androthrips flavipes } \\
\text { (Tubulifera: Phlaeothripidae) }\end{array}$ & $\begin{array}{l}\text { Liothrips himalayanus } \\
\text { Ananthakrishnan \& Jagadish }\end{array}$ & Schefflera sp. \\
\hline 5 & $\begin{array}{l}\text { Androthrips flavitibia* } \\
\text { (Tubulifera: Phlaeothripidae) }\end{array}$ & Liothrips bosei Moulton & Galls of Mallotus sp. \\
\hline 6 & $\begin{array}{l}\text { Androthrips ramachandrai } \\
\text { (Tubulifera: Phlaeothripidae) }\end{array}$ & $\begin{array}{l}\text { Gigantothrips elegans Zimm. and Gynaiko- } \\
\text { thrips bengalensis Ananthakrishnan }\end{array}$ & $\begin{array}{l}\text { Unidentified pouch galls of wild } \\
\text { plants }\end{array}$ \\
\hline 7 & $\begin{array}{l}\text { Franklinothrips megalops } \\
\text { (Terebrantia:Aelothripidae) }\end{array}$ & Thrips hawaiiensis (Morgan) & Morus alba L. leaves \\
\hline 8 & $\begin{array}{l}\text { Franklinothrips vespiformis } \\
\text { (Terebrantia: Aelothripidae) }\end{array}$ & $\begin{array}{l}\text { Scirtothrips dorsalis Hood, Thrips hawaiien- } \\
\text { sis (Morgan) }\end{array}$ & $\begin{array}{l}\text { Tea leaves and Avocado tree } \\
\text { foliage }\end{array}$ \\
\hline 9 & $\begin{array}{l}\text { Indothrips bhusani* } \\
\text { (Terebrantia: Aelothripidae) }\end{array}$ & Liothrips spectabilis Ananthakrishnan & Ficus leaves \\
\hline 10 & $\begin{array}{l}\text { Karnyothrips flavipes } \\
\text { (Tubulifera: Phlaeothripidae) }\end{array}$ & Anaphothrips sudanensis Trybom & $\begin{array}{l}\text { Setaria italica (Linn.) Beauv. } \\
\text { (Poaceae) }\end{array}$ \\
\hline 11 & $\begin{array}{l}\text { Mymarothrips garuda } \\
\text { (Terebrantia:Aelothripidae) }\end{array}$ & Pancheatothrips indicus Bagnall & Leaves of Curcuma longa $\mathrm{L}$. \\
\hline 12 & $\begin{array}{l}\text { Scolothrips asura } \\
\text { (Terebrantia:Thripidae) }\end{array}$ & Thrips sp. & $\begin{array}{l}\text { Leaves and flowers of field } \\
\text { crops }\end{array}$ \\
\hline
\end{tabular}

*Endemic species

but also found to be more efficient in predation than males (Arakaki et al., 2001). Therefore, producing more thelytokous individuals enable in checking the field density of pest species. Although a detailed list of predatory thrips of India and their host range in general have been provided by Ananthakrishnan (1976; 1984), the present paper supplements the species composition from the northeastern region (which is hitherto unknown), besides providing key to identify them along with revised nomenclature, as instances like Aduncothrips (=Erythrothrips) asiaticus and Aeolothrips (=Coleothrips) collaris (Bhatti, 1990; ThripsWiki, 2017).

From the view point of mass production and conservation of predatory thrips, the following method will facilitate to some extent to achieve our objective. Predatory thrips can be multiplied in the laboratory by providing thrips larvae, small soft bodied insect pests and mites (Table 1). Flower thrips reared in the lab \{as per the methods of Murai and Ishi (1982) and Murai (1990) using pollen and honey as food \} form the primary sources of food to the predatory thrips. Further, it has been observed that monoculture crops are one of the good sources to collect predatory thrips like Franklinothrips vespiformis from the tea growing areas and subsequently they can be mass reared in the laboratory for further field release. During the present survey, majority of the predators were collected from the national parks and wildlife sanctuaries, where application of pesticide doesn't happen at all with the exception of certain pockets with termite or other stem borer infestation and hence such areas could be considered as yet another zone for conservation of predators. Although a dozen species of thrips has been listed here as bio-control agents, among them, species under the genera Franklinothrips and Mymarothrips appear to be more operative and promising candidates for pest suppression under field condition.

\section{ACKNOWLEDGEMENT}

Thanks are due to the Coordinator, Centre of Advanced study in Life Sciences, Manipur University and the Director, NBAIR, Bengaluru for encouragement and to the DST, New Delhi for financial support. This paper is dedicated to Prof. J. S Bhatti, University of Delhi for his outstanding contribution in the field of Thysanoptera.

\section{REFERENCES}

Ananthakrishnan TN. 1976. The distribution and host range of predatory thrips. Indian J Pl Prot. 4(1): 67-78.

Ananthakirshnan TN. 1984. Bioecology of Thrips. Indira Publishing Company, USA.

Ananthakrishnan TN, Sen S. 1980. Taxonomy of Indian Thysanoptera. Handbook series No.1. Zoological survey of India pp. 234 PMCid:PMC1048540 
Arakaki N, Miyoshi T, Noda H. 2001. Wolbachia-mediated parthenogenesis in the predatory thrips Franklinothrips vespiformis (Thysanopera: Insecta). Proc Biol Sc. 268(1471): 1011-1016. https: // doi. org / 10. 1098/rspb. 2001. 1628 PMid:11375084 PMCid:PMC1088702

Arakaki N, Okajima S. 199. Notes on the biology and morphology of a predatory thrips, Franklinothrips vespiformis (Crawford) (Thysanoptera: Aeolothripidae): First record from Japan. Entomol Sci. 1: 359-363.

Bhatti JS. 1990. Catalogue of insects of the Order Terebrantia from Indian subregion. Zoology 2(4): 205-352.

Bhatti JS. 1997. Thysanoptera in Fauna of Delhi. State Fauna Series ZSI, Dehradun 6: 291-324.

Blaeser P, Sengonca C, Zegula T. 2004. The potential use of different predatory bug species in the biological control of Frankliniella occidentalis (Pergande) (Thysanoptera: Thripidae). J Pest Sci. 77: 211-9. https:// doi.org/10.1007/s10340-004-0057-2

Cox PD, Matthews L, Jacobson RJ, Cannon R, MacLeod A, Walters KFA. 2006. Potential for the use of biological agents for the control of Thrips palmi (Thysanoptera: Thripidae) outbreaks. Biocontr Sci Techn.16: 871-891. https://doi.org/10.1080/09583150600827728

Fathi SAA, Asghar A, Sedghi M. 2008. Interaction of Aeolothrips intermedius and Orius niger in controlling Thrips tabaci on Potato. Int J Agric Biol. 10(5): 521525.

Hirose Y, Kajita H, Takagi MS, Okajima, Napompeth B, Buranapanichpan S. 1993. Natural enemies of Thrips palmi and their effectiveness in the native habitat, Thailand. Biol Control 3: 1-5. https://doi.org/10.1006/ bcon.1993.1001

Hoddle MS, Oevering P, Philips PA. 2004. Evaluation of augmentative releases of Franklinothrips orizabensis for control of Scirtothrips perseae in California avocado orchards. Biol Control 30: 456-465. https://doi. org/10.1016/j.biocontrol.2004.01.009

Lewis T. 1973. Thrips: Their biology, ecology and economic importance. Academic Press, London, UK.

Kirk WDJ. 1997. Feeding thrips as crop pests. CAB International, Wallingford, UK, pp. 119-174.
Moritz G, Mound LA, Morris DC, Goldarazena A. 2004. Pest thrips of the world: CD-Rom. Brisbane Cent Biol Inf Technol.

Morse JG, Hoddle MS. 2006. Invasion biology of thrips. Ann Rev Entomol. 51: 67-89. https://doi.org/10.1146/ annurev.ento.51.110104.151044 PMid:16332204

Mound LA. 1997. Biological diversity. - In: Lewis T. (Ed.), Thrips as Crop Pests. CABInternational, Wallingford, 197-215.

Mound LA, Marullo R. 1998. Biology and identification of Aeolothripidae (Thysanoptera) in Australia. Invertebr Taxonomy 12: 929-950. https://doi.org/10.1071/IT97014

Mound LA, Reynaud P. 2005. Franklinothrips; a pantropical Thysanoptera genus of ant-mimicking obligate predators (Aeolothripidae). Zootaxa 864: 1-16. https: // doi.org/ 10.11646/ zootaxa. 864.1.1

Mound LA, Wheeler GS, Williams DA. 2010. Resolving cryptic species with morphology and DNA; thrips as a potential biocontrol agent of Brazilian pepper tree, with a new species and overview of Pseudophilothrips (Thysanoptera). Zootaxa 2432: 59-68.

Murai T. 1990. Rearing method and biology of thrips parasitoid, Ceranisus menes. SROP/WPRS Bull. XIII/5:142-416.

Murai T, Ishii T. 1982. Simple rearing method for flower thrips (Thysanoptera: Thripidae) on pollen. Jpn J Appl Entomol Zool. 26: 149-154. https://doi.org/10.1303/ jjaez.26.149

Okajima S, Hirose Y, Kajita H, Takagi M, Napompeth B, Buranapanichpan S. 1992. Thrips on fruit vegetables in South east Asia. Appl Entomol Zool. 27: 300-303. https://doi.org/10.1303/aez.27.300

Saengyot S. 2016. Predatory thrips species composition, their prey and host plant association in Northern Thailand. Agri Nat Res. 50(5): 1-24. https://doi.org/10.1016/j. anres.2015.10.002

THRIPSWIKI. 2017. ThripsWiki - providing information on the World's thrips. Available from: thrips.info/wiki/

Tommasini MG, Nicoli G. 2002. Evaluation of orius species for biological control of Frankliniella occidentalis (Pergande) (Thysanoptera: Thripidae), pp: 1-215. Ponsen and Looijenb.v.Wageningen. 